\title{
Genetic, environmental and interaction effects on the incidence of jacking in Oncorhynchus tshawytscha (chinook salmon)
}

\author{
DANIEL D. HEATHT, ROBERT H. DEVLIN $\dagger$, JOHN W. HEATH $\$$ \& GEORGE K. IWAMA* \\ Department of Animal Science and the Canadian Bacterial Diseases Network, University of British Columbia, 2357 Main \\ Mall, Suite 248, Vancouver, BC, Canada V6T 1Z4, †Department of Fisheries and Oceans, Canada, West Vancouver \\ Laboratories, 4160 Marine Drive, West Vancouver, BC, Canada V7V 1N6 and $\ddagger$ Yellow Is/and Aquaculture Ltd, 1681 Brook \\ Crescent, Campbel/ River, BC, Canada V9W 6K9
}

\begin{abstract}
Jacking in chinook salmon, Oncorhynchus tshawytscha, is defined as sexual maturation of males after at least 1 year in sea water, occurring 1 year prior to any of the females of the same cohort. A breeding experiment was carried out with jack and non-jack sires nested within six dams. The resulting 12 families were reared under two different temperatures for the first part of their lives to test for the effect of early developmental acceleration on jacking rates. Significant sire age (jack vs. non-jack), dam and environment (water temperature) effects were found for the incidence of jacking. Significant genotype-by-environment interactions were also found, indicating that accelerated early development does not increase jacking rates uniformly across all genotypes. There were no significant correlations between mean family growth- and size-related variables and the observed jacking rates. Heritability estimates based on intra-dam sire-offspring regressions were $0.48( \pm 0.24)$ and $0.32( \pm 0.14)$ for the accelerated and non-accelerated family groups, respectively. The results of sib-analysis heritability calculations indicated large dominance effects or sex linkage. The genetic component to jacking found in this study for chinook salmon was greater than has been generally reported for age of first maturation in salmonids.
\end{abstract}

Keywords: heritability, jacking, Oncorhynchus tshawytscha, precocious sexual maturation.

\section{Introduction}

Coastal chinook salmon (Oncorhynchus tshawytscha) spawn in fresh water and the fry generally migrate to sea water after over-wintering in the fresh water (Healey, 1991). Adult male chinook salmon may sexually mature and return to fresh water after only one year at sea, before any of the females in the same year class. This phenomenon, referred to as 'jacking' (Healey, 1991; Heath et al., 1991), occurs in most natural and hatchery stocks of chinook salmon. As jacks are generally the youngest, and thus the smallest, of the returning mature fish, they are considered undesirable by both commercial and sports fishermen. Until recently, jacks were routinely excluded from the breeding programme of the Salmon Enhancement Programme (SEP) in Western Canada. However, the incidence of jacking in those hatchery stocks is still

*Correspondence.

TPresent address: Department of Biology, University of South Carolina, Columbia, SC 29208, USA. higher than in wild stocks (Bocking \& Nass, 1992), despite the selection against that trait.

There is little published evidence of a genetic component to jacking in chinook salmon although Hard et al. (1985) showed a strain effect on the incidence of jacking in transplanted stocks of chinook salmon in Alaska. The bulk of the detailed genetic work on precocious sexual maturation in salmonids has been with Atlantic salmon (Salmo salar) juveniles and first year seawater adults (Naevdal et al., 1978; Naevdal, 1983; Thorpe et al., 1983; Gjerde, 1984; Glebe \& Saunders, 1986; Myers et al., 1986). There has been little detailed genetic research on the incidence of precocious maturation in salmonids subsequent to seawater migration, perhaps because of the logistic difficulties of rearing large numbers of adult fish in seawater facilities.

Environmental effects can be significant determinants of the age at sexual maturation in salmonids (Alm, 1959; Gardner, 1976; Randall et al., 1986; Thorpe, 1991). Generally, growth- or development- 
related environmental effects are most often reported as influencing the incidence of precocious maturation in salmonids (Thorpe, 1991). Experience in the SEP programme in British Columbia, Canada, has shown that growth acceleration in fresh water is associated with higher jacking rates in coho (Oncorhynchus kisutch) and chinook salmon (Bilton, 1980, 1984); however, these observations were based on very modest returns. Although the effect of accelerated growth on the incidence of jacking in chinook salmon is not fully understood, it probably has some effect on jacking rates. This study was designed to test for the effects of sire age (i.e. jack vs. non-jack male parent), dam, water temperature during early rearing (environment) and the interactions of these factors on the incidence of jacking in a captive population of chinook salmon.

\section{Materials and methods}

\section{Mating design and incubation}

In September 1989, over 100 sexually maturing male and female chinook salmon (first generation domestic Robertson Creek stock) were taken at random from multiple seine sets at the saltwater rearing facilities of Yellow Island Aquaculture Ltd (YIAL, Quadra Island, British Columbia, Canada) and transferred to freshwater facilities (aerated well water). On 9 November 1989, six 3-year-old females were spawned and the eggs from each female were divided into two approximately equal groups. Half of the eggs from each female were fertilized by 2-year-old males (jacks) while the other half were fertilized by 3-year-old males (nonjacks). Each male was used only once and all fertilizations took place within $2 \mathrm{~h}$ of gamete collection. The resulting 12 families were further divided into two subgroups (Table 1). The development of one of these subgroups was accelerated by incubating the eggs and fry in heated water (average $10.2^{\circ} \mathrm{C}$; range $9.0-11.1^{\circ} \mathrm{C}$ ) while the other subgroup was incubated in unheated water (average $8.0^{\circ} \mathrm{C}$; range $7.4-9.0^{\circ} \mathrm{C}$ ). All family groups were incubated in vertical stack incubation trays (Heath Technicorp., Seattle, Washington) with flows of $12-16 \mathrm{l} / \mathrm{min}$. The eggs were disinfected two or three times per week with Malachite green (50-100 $\mathrm{mg} / \mathrm{l}$ for 5-10 min. followed by flushing with fresh water) until the eyes of the developing embryo were clearly visible (eyed stage; approximately 30 days at $10^{\circ} \mathrm{C}$ ). To identify and remove non-viable eggs, eyed eggs were physically shocked by pouring them from a height of $0.5 \mathrm{~m}$ into water. This shock caused the nonviable eggs to turn opaque and these were removed; the viable eggs were not affected. By 3 January 1990, the accelerated (Acc) family groups were hatched and by 7 February the fry had reached swim-up stage (yolk sac fully absorbed). The fish in the non-accelerated (NAcc) family groups were hatched by 21 January 1990 and those fry reached swim-up stage by 13 March 1990 .

Table 1 Survival, estimated sex ratios (percentage males) and numbers of fish sexed for 24 full- and half-sib family groups used for the analysis of the genetic and environmental contributions to the incidence of jacking in chinook salmon

\begin{tabular}{|c|c|c|c|c|c|}
\hline Dam & $\begin{array}{l}\text { Sire } \\
(N / J)\end{array}$ & $\begin{array}{l}\text { Environment } \\
\text { (Acc/N-Acc) }\end{array}$ & $\begin{array}{l}\text { Survival } \\
(\%)\end{array}$ & $\begin{array}{l}\text { Sex ratio } \\
(\% \text { males })\end{array}$ & $\begin{array}{l}\text { Number } \\
\text { sexed }\end{array}$ \\
\hline \multirow[t]{4}{*}{1} & $\mathrm{~N}$ & Acc & 12 & 54 & 57 \\
\hline & $\mathbf{J}$ & Acc & 14 & 50 & 32 \\
\hline & $\mathrm{N}$ & N-Acc & 15 & 48 & 29 \\
\hline & $\mathbf{J}$ & N-Acc & 33 & 43 & 30 \\
\hline \multirow[t]{4}{*}{2} & $\mathrm{~N}$ & Acc & 20 & 53 & 36 \\
\hline & $\mathbf{J}$ & Acc & 20 & 44 & 68 \\
\hline & $\mathrm{N}$ & N-Acc & 19 & 37 & 30 \\
\hline & $\mathbf{J}$ & N-Acc & 29 & 57 & 30 \\
\hline \multirow[t]{4}{*}{3} & $\mathrm{~N}$ & Acc & 5 & 40 & 25 \\
\hline & $\mathbf{J}$ & Acc & 8 & 48 & 25 \\
\hline & $\mathrm{N}$ & N-Acc & 10 & 35 & 23 \\
\hline & $\mathbf{J}$ & N-Acc & 19 & 50 & 20 \\
\hline \multirow[t]{4}{*}{4} & $\mathrm{~N}$ & Acc & 11 & 54 & 24 \\
\hline & $\mathbf{J}$ & Acc & 26 & 44 & 45 \\
\hline & $\mathrm{N}$ & N-Acc & 18 & 47 & 30 \\
\hline & $\mathbf{J}$ & N-Acc & 26 & 50 & 30 \\
\hline \multirow[t]{4}{*}{5} & $\mathrm{~N}$ & Acc & 29 & 49 & 75 \\
\hline & $\mathbf{J}$ & $\mathrm{Acc}$ & 40 & 49 & 69 \\
\hline & $\mathrm{N}$ & N-Acc & 29 & 69 & 30 \\
\hline & $\mathbf{J}$ & N-Acc & 58 & 43 & 23 \\
\hline \multirow[t]{4}{*}{6} & $\mathrm{~N}$ & Acc & 15 & 36 & 25 \\
\hline & $\mathbf{J}$ & Acc & 10 & 56 & 27 \\
\hline & $\mathbf{N}$ & N-Acc & 29 & 65 & 17 \\
\hline & $\mathbf{J}$ & N-Acc & 11 & 42 & 24 \\
\hline \multicolumn{2}{|c|}{ Totals } & & 21 & 48.5 & 824 \\
\hline
\end{tabular}

Family groups arose from six dams mated with 12 sires (six jacks: J, and six third-year spawners: $N$ ) nested within dams. All families were incubated at two temperatures (accelerated, Acc; non-accelerated, N-Acc).

The totals are the overall survival, sex ratio, and the total number of fish sexed. 


\section{Early rearing}

At swim-up, each family (500-1000 fry) was randomly assigned to one of 24 identical $200 \mathrm{l}$ outdoor tanks. All tanks received equal water flows $(15 \mathrm{l} / \mathrm{min})$ from a common source (average $8.8^{\circ} \mathrm{C}$; range $7.8-10.0^{\circ} \mathrm{C}$ ). Note that no within-treatment replication was possible due to limitations on the total number of fish reared to sexual maturation. Fry were fed during daylight hours with automatic feeders, eight times per hour for 14 days after swim-up. Subsequently, the fry were fed to satiation by hand four times per day. The fry were fed Biomoist starter diet (Bioproducts Ltd., Warrenton, Oregon) until they reached $1.2 \mathrm{~g}$ when they were switched to a semi-moist diet (Moore Clarke Canada, Vancouver, British Columbia). Mortalities were removed daily.

\section{Tagging}

On 8 May and 23 May 1990, 500 fry from each of the 12 Acc and N-Acc family groups were anaesthetized $(0.15 \mathrm{ml} / \mathrm{l}$ 2-phenoxyethanol) and a coded wire nose tag implanted (Jewell \& Hager, 1972). Twenty-four differently coded nose tags were used, thus all fish could be identified as to family of origin as well as to Acc or N-Acc groups. After the tagging, the fry were transferred to four $3000 \mathrm{l}$ indoor tanks. Six Acc families were randomly assigned to each of two tanks and the N-Acc families were similarly assigned to two of the tanks.

\section{Rearing}

On 22 May 1990, the Acc family groups (average $4.0 \mathrm{~g}$ ) were dip-vaccinated against vibriosis following the vaccine manufacturer's instructions (Microtek Inc., Victoria, British Columbia) and on 13 June 1990, the $\mathrm{N}$-Acc family groups (average $3.7 \mathrm{~g}$ ) were similarly vaccinated. The Acc family groups (average $8.4 \mathrm{~g}$ ) were transferred to seawater grow-out facilities on 30 June 1990, after a 2 week acclimation period of 25 per cent pumped seawater, and the N-Acc groups (average $7.3 \mathrm{~g}$ ) were similarly transferred on July 19, 1990. All of the Acc family groups were reared in one seawater netcage, while the N-Acc family groups were reared in an adjacent netcage. The seawater netcages were initially $5 \mathrm{~m} \times 10 \mathrm{~m} \times 10 \mathrm{~m}$ enclosures and later $10 \mathrm{~m} \times 10 \mathrm{~m} \times 10 \mathrm{~m}$ enclosures. Throughout the seawater rearing period, mortalities were removed weekly by scuba divers. The fish were fed to satiation one or two times daily using a commercially available diet (White Crest Mills, Campbell River, British Columbia). The Acc and N-Acc fish were sampled approximately monthly for weight.
In the late summer of 1990, the Acc and N-Acc family groups both experienced acute losses from vibriosis (on a presumptive diagnosis from 19-22 August for the Acc fish and from 7-10 October for the $\mathrm{N}$-Acc fish), in both cases the fish were treated for 8 days with antibiotic $(0.167 \mathrm{~g} \mathrm{~kg} /$ day Romet; Syndel Laboratories, Vancouver, British Columbia). On 9 and 10 December 1990, 415 Acc fish and 439 N-Acc fish were removed at random from the netcages, killed with an overdose of 2-phenoxyethanol $(2.5 \mathrm{~mol} / \mathrm{l})$, weighed $( \pm 0.1 \mathrm{~g}$ ), blood samples taken from the caudal vasculature and their nose tags removed for subsequent decoding to identify the fish to family of origin. At this time the total number of fish remaining in each of the two netcages was determined. In March 1991, a further 425 fish were removed from the Acc family groups and sampled as described above.

\section{Final sample}

By September 1991, the sexually mature males (jacks) were easily distinguished based on body morphology and skin colour. On 19 and 20 September 1991, all the jacks in both the Acc and N-Acc family groups were individually sorted, anaesthetized in $\mathrm{CO}_{2}$ saturated water and killed. The total wet weight and testes weight was measured and the nose tag recovered and decoded for each jack. The remaining non-mature fish were commercially harvested during the fall of 1991; at the time of harvest they were individually weighed and their nose tags recovered for decoding.

\section{Analysis}

The sex ratio for each family was estimated using a Y-chromosomal sex probe for chinook salmon (Devlin et al., 1991) using DNA from blood samples for all family groups taken from randomly selected fish prior to sexual maturation of the jacks (i.e. December 1990 sample and March 1991 sample). The sex ratio estimate was based on 17-75 sexed fish per family (Table 1).

Jacking rate was calculated as the total number of jacks in each family divided by the total number of surviving fish in that family (including the jacks). The male-specific jacking rate (SJR) or the percentage of male fish that jacked, was calculated as follows:

$\mathrm{SJR}=\mathrm{JR} \times \mathrm{SR}^{-1} \times 100 \%$,

where JR was the jacking rate and SR was the estimated sex ratio (Table 1).

A hierarchical series of log-linear models were used to test for the effect of rearing environment (i.e. Acc vs. $\mathrm{N}$-Acc), male parent (i.e. jack vs. 3-year-old), female parent and interactions on the observed jacking rates 
(sYSTAT, Evanston, IL, USA). The statistical significance of the various terms was determined by calculating the change in the log-likelihood statistic with the removal of the effect in question from the saturated model (Fienberg, 1970).

Two approaches were used to estimate the heritability of jacking in the population of chinook salmon at Yellow Island Aquaculture Ltd. The first was parent-offspring regressions of the jack $($ value $=1$ ) and non-jack (value $=0$ ) sires nested within a single dam on the incidence of jacking (ratio) in the full-sib offspring. Six regression coefficients were generated for the Acc and N-Acc family groups separately; these were averaged to yield a mean regression coefficient (and standard error). Heritabilities for the Acc and N-Acc groups were calculated by multiplying the mean slope by two, as described by Falconer (1981) for nested parent-offspring regressions. The second method used to estimate heritability was based on an ANOVA on the incidence of jacking in the Acc and N-Acc groups separately. The model used was:

$Y_{\mathrm{ijk}}=\mu+D_{\mathrm{k}}+S_{\mathrm{jk}}+e_{\mathrm{ijk}}$,

where $Y_{\mathrm{ijk}}$ was the sexual maturation status (i.e. 0 -male or 1 -jack) of the $i$ th progeny of the $j$ th sire nested within the $k$ th dam, $\mu$ was the population (least square) mean, $D_{\mathrm{k}}$ was the random effect of the $k$ th dam, $S_{\mathrm{jk}}$ was the random effect of the $j$ th sire nested within the $k$ th dam, and $e_{\mathrm{ijk}}$ was the random error term. As the number of surviving progeny varied widely between families (and thus the ANOVA would be unbalanced), an approximately equal number of progeny was chosen at random for each family for inclusion in the analysis. The data in this analysis consisted of zeros and ones and thus the assumption of normality for ANOVA (Sokal \& Rohlf, 1981) was violated. However, because the incidence of jacking in most families was high the ANOVA is robust to non-normality (Sokal \& Rohlf, 1981; Iwamoto et al., 1984). Furthermore, the ANOVA was used only for estimating mean squares and not for significance testing. Heritabilities for both the Acc and the N-Acc family groups were estimated using the calculated and expected mean squares (following Falconer, 1981).

All estimated heritabilities were corrected to the continuous liability scale (van Vleck, 1972; Falconer, 1981; Iwamoto et al., 1984) using:

$h^{2}=h_{\mathrm{b}}^{2} z^{2}[p(1-p)]^{-1}$,

where $h^{2}$ is the continuous scale heritability, $h_{\mathrm{b}}^{2}$ is the binomial scale heritability (calculated from a threshold phenotype), $z$ is the ordinate of the normal distribution at the threshold point which divides jacks from nonjacking males and $p$ is the frequency of jacking in the offspring (Iwamoto et al., 1984).
A correlation analysis of growth- and size-related variables with jacking rates for the 24 family groups was performed. Nine weight-at-age variables and two growth rate variables were regressed against jacking rate. The growth rates were for two periods during freshwater rearing (prior to saltwater introduction) and the weight measurements were: eyed egg weight, wet weight at yolk sac absorption, four points during freshwater growth, wet weight at December 1990 and the wet weights of the maturing (jack) and non-maturing fish at the final sampling in September 1991. The regression model used was:

$\mathrm{SJR}=\mathrm{CONSTANT}+\mathrm{S}+\mathrm{D}+\mathrm{E}+\mathrm{X}$,

where SJR was the specific jacking rate, $S$ was a categorical variable for the effect of sire age, $D$ was a categorical variable for the effect of the dam, $E$ was a categorical variable for the effect of the two environments (Acc and N-Acc) and X was the family mean of the parameter under analysis. All percentages were arcsin square-root transformed and all other (noncategorical) variables were natural logarithm transformed (Sokal \& Rohlf, 1981).

\section{Results}

\section{Growth}

Although the Acc and N-Acc family groups grew at similar rates throughout the duration of the experiment, the fish in the Acc groups were generally larger than the fish in the N-Acc groups (Fig. 1a) as well as having slightly higher absolute growth rates (Fig. 1b).

\section{Survival and sex ratios}

There were large differences in the survival of the various family groups within the Acc and N-Acc environments from the time of marking to the final sampling in September 1991 (Table 1). Most of the mortality occurred after the fish were transferred to salt water; as of December 1990, 65 per cent of the Acc and 58 per cent of the N-Acc remained. Although most families had roughly equal numbers of males and females, a few had skewed sex ratios (Table 1). The population sex ratio was not significantly different from 50:50 (chi-squared test; $P>0.10$ ).

\section{Jacking rates}

Overall jacking rates (percentage jacks in population) were 19.5 per cent for the Acc group and 17.3 per cent for the N-Acc group. The specific jacking rates (SJR) 

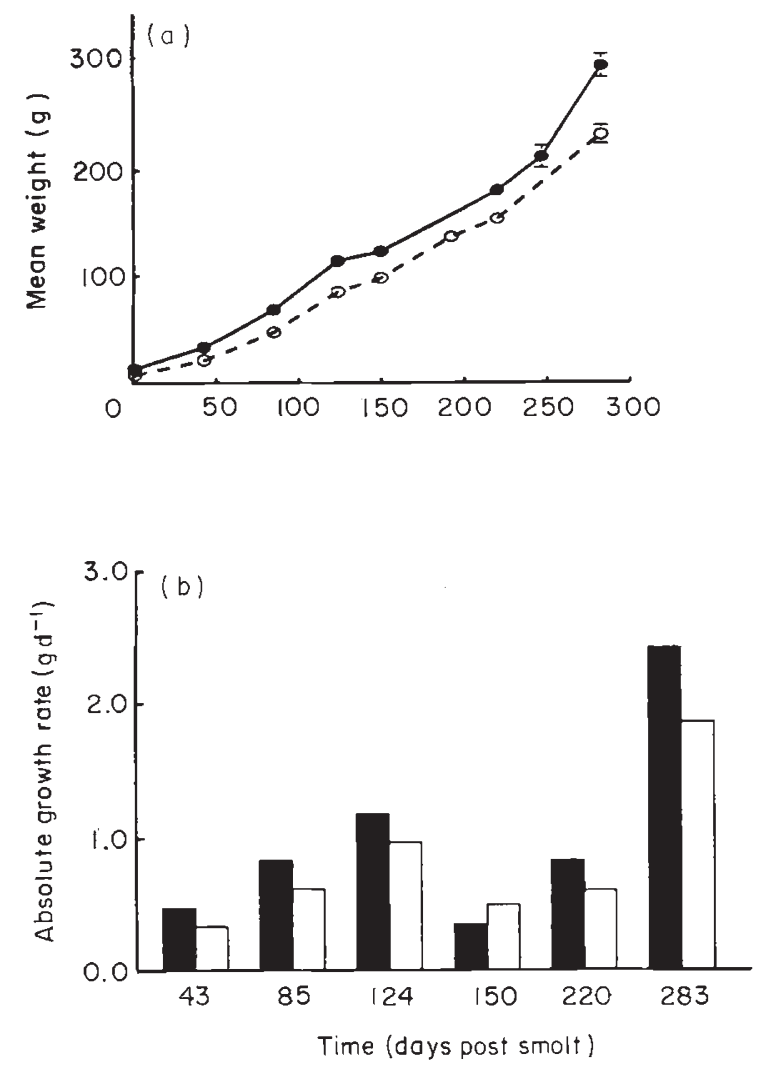

Fig. 1 (a) Mean wet weight ( \pm S.E.) of the accelerated (Acc) and non-accelerated (N-Acc) chinook salmon family groups used in the analysis of jacking rates plotted against time. (b) Absolute growth rate (i.e. linear slope of weight vs. time) of the accelerated (Acc) and non-accelerated (N-Acc) chinook salmon family groups.

varied between and within the Acc and N-Acc groups (Fig. 2a and b). There was a significant effect of environment (Acc vs. N-Acc) on the observed jacking rates $(G=14.9$; d.f. $=1 ; P<0.001)$ with the Acc groups having a higher jacking rate. There was a significant dam effect on the observed frequencies of jacking $(G=231 ;$ d.f. $=5 ; P<0.001)$, as well as a significant sire effect (jack vs. non-jack) on the observed frequencies $(G=22.2 ;$ d.f. $=1 ; P<0.001)$. The interaction effect of dam-by-environment was significant $(G=22.7$; d.f. $=5 ; \quad P<0.001)$ as was the sire-byenvironment interaction $(G=9.43$; d.f. $=1 ; P<0.003)$. However, the norms of reaction for jacking rate across the two environments (Fig. $3 \mathrm{a}$ and b) show that the significant genotype-by-environment interactions were mainly due to two families (dam 6 by jack sire and dam 3 by non-jack sire) and these families had relatively low survivals (Table 1). The three-way interaction (sire-bydam-by-environment) was non-significant.

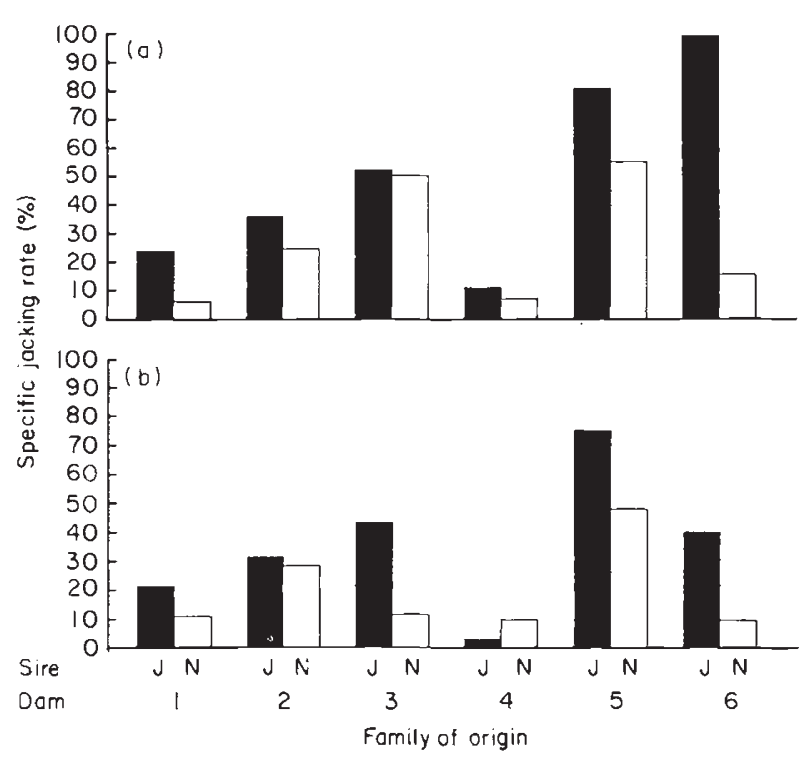

Fig. 2 Specific jacking rates (\%) for the 24 chinook salmon family groups; (a) 12 accelerated families; (b) 12 non-accelerated families. Specific jacking rate is the ratio of jacks to the estimated total number of males (see text). The families are the progeny of six dams $(1-6)$ each mated to two males; one jack $(\mathrm{J})$ and one 3-year-old or non-jack, male $(\mathrm{N})$.

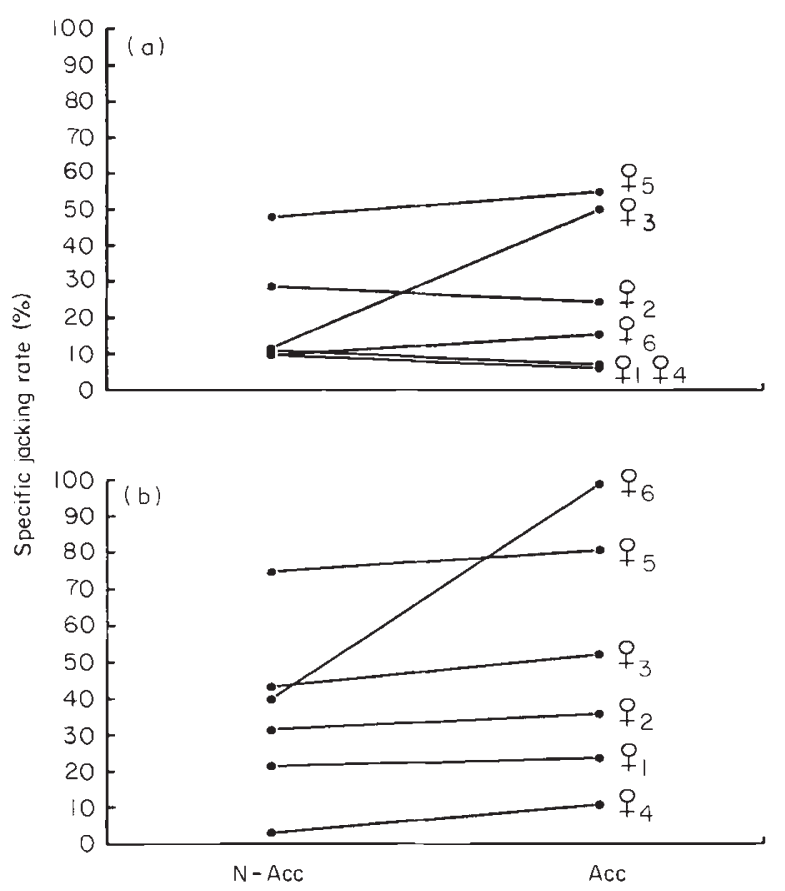

Fig. 3 Norms of reaction for the observed specific jacking rates in the 12 full- and half-sib chinook salmon family groups reared under accelerated $(\mathrm{Acc})$ and non-accelerated ( $\mathrm{N}$-Acc) conditions. The norms of reaction are shown for (a) jack-sired, (b) non-jack sired families separately. Each line represents a single family and the dam of the family is shown on the right. Genotype-by-environment interaction is identified by non-parallel lines (i.e. relative family rank changes with environment). 


\section{Heritability}

The heritability estimates from the Acc and N-Acc groups based on regressions of sire on male offspring (within dam) and sib-analysis are presented in Table 2. Standard errors are given for the estimates based on the parent-offspring regressions; however, due to the limited number of families used in the sib-analysis, no estimates of standard error were calculated. Continuous liability scale heritability estimates are also given in Table 2. Note that the sire component heritability estimates exceed 1.0 when converted to the continuous scale, indicating probable non-additive effects.

\section{Correlation analysis}

None of the growth or size-related variables was significantly correlated with family jacking rates at the $P<0.05$ probability level.

\section{Discussion}

The effect of sire age (i.e. jack vs. non-jack) on the incidence of jacking was very clear; the SJR of jacksired fish was 44.8 per cent whereas the SJR of nonjack-sired fish was 26.9 per cent. Furthermore, for all cases except one, the jack-sired families had higher jacking rates than their non-jack-sired half-sibs (Fig. 2a and b). Therefore, within the population of chinook salmon examined, it is clear that jacking incidence could be profoundly affected by the choice of sires. Similar results have been reported for coho and Atlantic salmon precocious parr (Thorpe et al., 1983; Gjerde, 1984; Iwamoto et al., 1984; Glebe \& Saunders, 1986). A genetic component to precocious sexual maturation has been demonstrated in many salmonid species. Breeding experiments designed to partition this genetic component into maternal and paternal contributions have been reported for Atlantic salmon (Naevdal et al., 1978; Naevdal, 1983; Thorpe et al., 1983; Gjerde, 1984; Glebe \& Saunders, 1986; Myers et al,, 1986), rainbow trout, Oncorhynchus mykiss (Moller et al., 1976; Gall \& Gross, 1978; Gall et al., 1988), Arctic charr, Salvelinus alpinus (Nilsson, 1992), and coho salmon (Iwamoto et al, 1984; Silverstein \& Hershberger, 1992).

In some fish, the age of first maturation in males has been shown to be controlled by simple genetic mechanisms. Glebe \& Saunders (1986) noted that in Atlantic salmon, their observed frequencies of precocious male parr could be explained by a single gene model whereas sexual maturation in some Xiphophorus spp. has been determined to be controlled by a single locus (Kallman \& Bao, 1982; Zimmerer \& Kallman, 1989). The present study showed that the sire
Table 2 Calculated heritabilities for jacking in farmed Robertson Creek chinook salmon stock

\begin{tabular}{llll}
\hline & & \multicolumn{2}{l}{ Sib-analysis } \\
\cline { 3 - 4 } Environment & Sire-offspring & Dam & Sire \\
\hline Acc & & & \\
$h_{\mathrm{b}}^{2}$ & $0.48( \pm 0.24)$ & 0.33 & 1.16 \\
$h^{2}$ & $0.77( \pm 0.39)$ & 0.53 & 1.86 \\
$\mathrm{~N}-$ Acc & & & \\
$h_{\mathrm{b}}^{2}$ & $0.32( \pm 0.14)$ & 0.22 & 0.73 \\
$h^{2}$ & $0.54( \pm 0.23)$ & 0.37 & 1.22 \\
\hline
\end{tabular}

The heritabilities were calculated from sire-male offspring regressions and sib-analysis (ANOVA) with progeny scored as ones (jacks) and zeros (non-mature males). Separate heritability estimates were made for the accelerated (Acc) and non-accelerated groups (N-Acc) and are presented as binomial scale estimates $\left(h_{\mathrm{h}}^{2}\right)$, as well as transformed to continuous scale estimates $\left(h^{2}\right)$.

Standard errors are given for the heritability estimates based on sire-male offspring regressions.

component $h^{2}$ for jacking in chinook salmon was greater than one; much larger than the dam component $h^{2}$. This, combined with the overall high heritability estimates, indicates that the sire component included strong dominance effects or that jacking was controlled by few loci; however, an analysis of $F_{2}$ progeny is necessary to test this. There is also evidence that jacking in chinook salmon may be sex linked. Two cohorts of female chinook salmon were hormonally masculinized (Hunter et al., 1983) at Yellow Island Aquaculture Ltd. These phenotypically male but genotypically female fish (XX males) had very low jacking rates ( 1.4 per cent in $1990, n=2300 ; 2.7$ per cent in 1991, $n=1500$ ) compared with jacking rates of genotypically male fish from similar stocks (30-40 per cent for both years). The incidence of third year maturation in the $\mathrm{XX}$ male fish was similar to that observed for the regular males.

Many of the genetic analyses of precocious sexual maturation in salmonids have been done on juveniles prior to seawater migration and one of the common problems faced by those analyses has been non-genetic maternal, or 'common environmental', effects (Falconer, 1981; see Iwamoto et.al., 1984). Nongenetic maternal effects have been identified as possible factors in the age of sexual maturation for precociously maturing salmonids (Bailey et al., 1980; Sutterlin \& MacLean, 1984; Nilsson, 1992; Silverstein \& Hershberger, 1992). Perhaps the most obvious nongenetic effect of a dam on her offspring is egg size, and hence early body size and growth; however, this effect 
decreases with age (Gall, 1974; Sutterlin \& MacLean, 1984; Withler et al., 1987; Silverstein \& Hershberger, 1992). A maternal effect on early growth could have a profound impact on estimates of the dam component of the observed variance in age at sexual maturation (Bradford \& Peterman, 1987; Silverstein \& Hershberger, 1992); however, Gall et al. (1988) showed that maternal effects on the age at spawning were very small in rainbow trout. Although it is unlikely that such an effect was a major factor in the present study (as jacking occurred 18 months post-hatch) non-genetic maternal effects cannot be ruled out.

In salmonids, there is substantial evidence for the age of first maturity being dependent on individual size and growth rate (Alm, 1959; Randall et al., 1986; Thorpe, 1986; see Heath et al., 1991). Lamont (1990) showed in individually tagged rainbow trout and coho salmon that the fastest growing individuals were the precociously maturing males. However, correlations between growth rate and precocious sexual maturation do not imply causation. In a controlled breeding experiment, Iwamoto et al. (1984) showed that there was no significantly higher incidence of precocious maturation in coho salmon in which early growth had been accelerated using heated water. Herbinger \& Friars (1992) also found no consistent effect of accelerated (or decelerated) growth on the incidence of early maturation in Atlantic salmon freshwater juveniles. In the present study, a statistically significant increase in jacking rate was found for the accelerated family groups; however, the magnitude of the difference was modest (17.3 per cent vs. 19.5 per cent). The lack of any correlation between jacking rates and family mean size at age (or growth rate) throughout their life, indicates that the higher jacking rates observed in the developmentally accelerated groups was probably not directly due to higher growth rates or size at age. The duration and intensity of the developmental acceleration (i.e. heated water) was limited in both the present study and that of Iwamoto et al. (1984) compared with that typical of commercial and government hatcheries. Herbinger \& Friars (1992) suggested that the energy reserve threshold for precocious maturation in Atlantic salmon freshwater juveniles may be relatively low and hence accelerated growth may not have a large effect. It may be that the effect of developmental acceleration early in life on the subsequent incidence of jacking within a family (i.e. increased jacking rates) may be distinct from the effect of naturally occurring differences in growth between families (i.e. no effect on jacking rates).

The presence of significant sire- and dam-byenvironment interaction effects indicates that growth acceleration early in life does not simply lower the threshold for jacking within all families alike (Fig. 3a and b). Although genotype-by-environment interactions have been found for temperature and growth in a number of salmonids (Iwamoto et al., 1984; McKay et al., 1984; Nilsson, 1992), few instances of genotypeby-environment interactions for temperature and sexual maturation have been reported (see Nilsson, 1992). The environmental effect in this study includes not only the early growth and size at age differences between the Acc and N-Acc family groups but also any other rearing effects due to the two groups being held in separate unreplicated netcages. It is therefore not possible to determine the exact environmental effects contributing to the interactions.

The estimates of heritability based on intra-dam regressions of male offspring on sire (Table 2) do not include dominance effects $\left(v_{\mathrm{D}}\right)$ and are not confounded by non-genetic maternal effects $\left(v_{\mathrm{CE}}\right.$; Falconer, 1981) and thus are the best heritability estimates possible within this study. Our heritability estimates for jacking in chinook salmon are considerably higher than is usually reported for age at first reproduction in salmonids (Table 3 ). The heritability estimates based on the sib-analysis have a number of limitations: (1) jacking is a threshold trait and is therefore scored on a

Table 3 Estimates of heritability for mean age of first maturation in salmonids taken from the literature

\begin{tabular}{|c|c|c|}
\hline Species & $h^{2}$ & Reference \\
\hline Chinook salmon & 0.30 & Ricker $(1980) \ddagger$ \\
\hline \multirow[t]{3}{*}{ Coho salmon $\dagger$} & $0.05^{\mathrm{s}}( \pm 0.05)$ & $\begin{array}{l}\text { Silverstein \& Hershberger } \\
\quad(1992)\end{array}$ \\
\hline & $0.13^{\mathrm{d}}( \pm 0.11)$ & $\begin{array}{l}\text { Silverstein \& Hershberger } \\
\quad(1992)\end{array}$ \\
\hline & 0.17 & Iwamoto et al.(1984) \\
\hline \multirow[t]{4}{*}{ Rainbow trout } & $0.21^{\mathrm{s}}$ & Gjerde \& Gjedrem (1984) \\
\hline & $0.26^{\mathrm{d}}$ & Gjerde \& Gjedrem (1984) \\
\hline & $0.09^{\mathrm{s}}$ & Moller et al. $(1976)$ \\
\hline & $0.01^{\mathrm{d}}$ & Moller et al. (1976) \\
\hline \multirow[t]{4}{*}{ Arctic charr } & $0.45^{\mathrm{s}}( \pm 0.17)$ & Nilsson (1992) \\
\hline & $0.12^{\mathrm{d}}( \pm 0.08)$ & Nilsson (1992) \\
\hline & $0.19^{s}( \pm 0.11)$ & Nilsson (1992) \\
\hline & $0.60^{\mathrm{d}}( \pm 0.24)$ & Nilsson (1992) \\
\hline \multirow[t]{3}{*}{ Atlantic salmon } & $0.39^{\mathrm{s}}$ & Gjerde \& Gjedrem (1984) \\
\hline & $0.49^{\mathrm{d}}$ & Gjerde \& Gjedrem (1984) \\
\hline & $0.48^{r}$ & Gjerde \& Gjedrem (1984) \\
\hline
\end{tabular}

Three methods of estimation are reported: sire component (s) and dam component (d) refer to sib analyses, presumably on the binomial scale, and parent-offspring regressions $(\boldsymbol{r})$. Standard errors were included when reported.

$\dagger=$ precocious maturation in freshwater.

‡Cited in Gjedrem (1984). 
binomial scale (i.e. ' 0 ' or ' 1 '), (2) the mating design (males nested within females) does not allow an unbiased estimate of heritability based on sib-analyses (Falconer, 1981), (3) the number of surviving fish varied widely across the families, and (4) only 12 families were used thus any estimate of heritability would have extremely large uncertainty associated with it. Nevertheless, the results were presented to show the differences between the sire and dam estimates. The dam-component heritability is biased by any nongenetic maternal effects $\left(0.25 \mathrm{~V}_{\mathrm{A}}+\mathrm{V}_{\mathrm{Ec}}\right)$, and the sirecomponent heritability includes dominance effects $\left(0.25 \mathrm{~V}_{\mathrm{A}}+0.25 \mathrm{~V}_{\mathrm{D}}\right)$. Since the sire-component of heritability is much larger than the dam-component it is likely that dominance effects $\left(\mathrm{V}_{\mathrm{D}}\right)$ are present (although some form of sex linkage would also account for the discrepancy).

The results of this study indicate that the phenomenon of jacking in chinook salmon has a strong inherited component and that the acceleration of early developmental rates do not uniformly increase the incidence of jacking (within the population studied). Further research into the nature of the genotype-byenvironment interaction, as well as possible dominance effects, is warranted.

\section{Acknowledgements}

We thank N. Bernier, N. Johnson, W. Harrower, V. A. Heath, J. Smit, M. Heath and D. T. Heath for their help in the field and the laboratory. Valuable comments and discussions were provided by Drs T. A. Mousseau (Department of Biological Sciences, USC), K. Cheng (Department of Animal Science, UBC), D. Schluter (Department of Zoology, UBC) and D. Roff (Department of Biology, McGill University). Funding and facilities for the breeding experiment was provided by Yellow Island Aquaculture Ltd. Funding was also provided by NSERC and Canadian Bacterial Disease Network operating grants to G.K.I. and a DFO operating grant to R.H.D. Personal funding was provided to D.D.H. through a STARS postgraduate award from the B.C. Science Council.

\section{References}

ALM, G. 1959. Connection between maturity, size and age in fishes. Rep. Inst. Freshwater Res., Drottningholm, 40, 5-145.

BAILEY, J. K., SAUNDERS, R. L. AND BUZETA, M. I. 1980. Influence of parental smolt age and sea age on growth and smolting of hatchery reared Atlantic salmon (Salmo salar). Can. J. Fish. Aquat. Sci., 37, 1379-1386.

BILTON, H. T. 1980. Returns of adult coho salmon in relation to mean size and time at release of juveniles to the catch and the escapement. Can. Tech. Rep. Fish. Aquat. Sci., 941, $1-41$.

BILTON, H. T. 1984. Returns of chinook salmon in relation to juvenile size at release. Can. Tech. Rep. Fish. Aquat. Sci., 1245, 1-33.

BOCKING, R. C. AND NASS, B. L. 1992. Stamp Falls fishway counts, adipose clip/CWT recovery and biological sampling of chinook salmon escapements in Stamp River and Robertson Creek Hatchery, 1991. Can. Manuscr. Rep. Fish. Aquat. Sci., 2172, 1-81.

BRADFORD, M. J. AND PETERMAN, R. M. 1987. Maternal size effects may explain positive correlations between age at maturity of parent and offspring sockeye salmon (Oncorhynchus nerka). In: Smith, H. D., Margolis, L. and Wood, C. C. (eds) Sockeye Salmon (Oncorhynchus nerka) Population Biology and Future Management, vol. 96, pp. 90-100. Can. Spec. Publ. Fish. Aquat. Sci., Ottawa

DEVLIN, R. H., MCNEIL, B. K., GROVES, D. D. AND DONALDSON, E. M. 1991. Isolation of a Y-chromosomal DNA probe capable of determining genetic sex in chinook salmon (Oncorhynchus tshawytscha). Can. J. Fish. Aquat. Sci., 48, 1606-1612.

FALCONER, D. S. 1981. Introduction to Quantitative Genetics, 2nd edn. Longman, New York.

FIENBERG, S. E. 1970. The analysis of multidimensional contingency tables. Ecology, 51, 419-433.

GALL, G. A. E. 1974. Influence of size of eggs and age of female on hatchability and growth in rainbow trout. Calif. Fish Game, 60, 26-35.

GALL, G. A. E., BALtODANO, J. AND HUANG, N. 1988. Heritability of age at spawning for raindow trout. Aquaculture, 68 , 93-102.

GALL, G. A. E. AND GROSS, S. J. 1978. A genetics analysis of the performance of three rainbow trout broodstocks. Aquaculture, 15, 113-127.

GARDNER, M. L. G. 1976. A review of factors which may influence the sea-age and maturation of Atlantic salmon Salmo salar L. J. Fish. Biol., 9, 289-327.

GJEDREM, T. 1984. Genetic variation in age at maturity and its relation to growth rate. In: Iwamoto, R. N. and Sower, S. A. (eds) Sea Grant Proceedings for International Symposium on Salmonid Reproduction, pp. 52-61. University of Washington Press, Seattle.

GJERDE, B. 1984. Response to individual selection for age at sexual maturity in Atlantic salmon. Aquaculture, 38, 229-240.

GJERDE, B. AND GJEDREM, T. 1984. Estimates of phenotypic and genetic parameters for carcass traits in Atlantic salmon and rainbow trout. Aquaculture, 36, 97-110.

GLEBE, B. D. AND SAUNDERS, R. L. 1986. Genetic factors in sexual maturity of cultured Atlantic salmon (Salmo salar) parr and adults reared in sea cages. In: Meerburg, D. J. (ed.) Salmonid Age at Maturity, vol. 89, pp. 24-29. Can. Spec. Publ. Fish. Aquat. Sci., Ottawa.

HARD, J. J., WERTHEIMER, A. C., HEARD, W. R. AND MARTIN, R. M. 1985. Early male maturity in two stocks of chinook salmon (Oncorhynchus tshawytscha) transplanted to an experimental hatchery in southeastern Alaska. Aquaculture, 48, 351-359. 
HEALEY, M. C. 1991. Life history of chinook salmon (Oncorhynchus tshawytscha). In: Groot, C. and Margolis, L. (eds) Pacific Salmon Life Histories, pp. 311-394. UBC Press, Vancouver.

HEATH, D. D., HEATH, J. W. AND IWAMA, G. K. 1991. Maturation in chinook salmon, Oncorhynchus tshawytscha (Walbaum): early identification based on the development of a bimodal weight-frequency distribution. J. Fish. Biol., 39, $565-575$.

HERBINGER, C. M. AND FRIARS, G. W. 1992. Effects of winter temperature and feeding regime on the rate of early maturation in Atlantic salmon (Salmo salar) male parr. Aquaculture, 101, 147-162.

HUNTER, G. A., DONALDSON, E. M., STOSS, J. AND BAKER, I. 1983. Production of monosex female groups of chinook salmon (Oncorhynchus tshawytscha) by the fertilization of normal ova with sperm from sex-reversed females. Aquaculture, 33, 355-364.

IWAMOTO, R. N., ALEXANDER, B. A. AND HERSHBERGER, W. K. 1984. Genotypic and environmental effects on the incidence of sexual precocity in coho salmon (Oncorhynchus kisutch). Aquaculture, 43, 105-121.

JEWEL, E. D. AND HAGAR, R. C. 1972. Field evaluation of coded wire tag detection and recovery techniques. In: Simon, R. C. and Larkin, P. A. (eds) The Stock Concept in Pacific Salmon: H. R. MacMillan Lectures in Fisheries, pp. 183190. UBC Press, Vancouver.

KALLMAN, K. D. AND BAO, I. Y. 1982. Genetic control of the hypothalamopituitary axis and the effect of hybridization on sexual maturity (Xiphophorus, Pisces, Poeciliidae). $J$. Exp. Zool., 200, 297-309.

LAMONT, C. A. 1990. The relationship between growth rate and precocious sexual maturation in rainbow trout (Oncorhynchus mykiss) and coho salmon (Oncorhynchus kisutch). M.Sc. Thesis, University of British Columbia, Vancouver, B.C.

MCKAY, L. R., FRIARS, G. W. AND IHSSEN, P. E. 1984. Genotype X temperature interactions for growth of rainbow trout. Aquaculture, 41, 131-140.

MOLLER, D., NAEVDAL, G., HOLM, M. AND LEROY, R. 1976. Variation in growth rate and age at sexual maturity in rainbow trout. FAO Technical Report FIR AQ/Conference, E.61, pp. $622-626$.

MYERS, R. A., HUTCHINGS, J. A. AND GIBSON, R. J. 1986. Variation in male parr maturation within and among population of
Atlantic salmon, Salmo salar. Can. J. Fish. Aquat. Sci., 43, 1242-1248.

NAEVDAL, G. 1983. Genetic factors in connection with age at maturation. Aquaculture, 33, 97-106.

NAEVDAL, G., HOLM, M., INGEBRIGTSEN, O. AND MOLLER, D. 1978. Variation in age at first spawning in Atlantic salmon (Salmo salar). J. Fish. Res. Board Can., 35, 145-147.

NiLsson, J. 1992. Genetic parameters of growth and sexual maturity in Arctic char (Salvelinus alpinus). Aquaculture, 106, 9-19.

RANDALL, R. G., THORPE, J. E., GIBSON, R. J. AND REDDIN, D. G. 1986. Biological factors affecting age at maturity in Atlantic salmon (Salmo salar). In: Meerburg, D. J. (ed.) Salmonid Age at Maturity, vol. 89, pp. 90-96. Can. Spec. Publ. Fish. Aquat. Sci., Ottawa.

SILVERSTEIN, J. T. AND HERShBerger, w. K. 1992. Precocious maturation in coho salmon (Oncorhynchus kisutch): estimation of the additive genetic variance. J. Heredity, $\mathbf{8 3}$, 282-286.

SOKAL, R. R. AND ROHLF, F. J. 1981. Biometry, 2nd edn. W. H. Freeman, San Francisco.

SUTTERLin, A. M. AND MAClEAN, D. 1984. Age at first maturity and the early expression of oocyte recruitment processes in two forms of Atlantic salmon (Salmo salar) and their hybrids. Can. J. Fish. Aquat. Sci., 41, 1139-1149.

THORPE, J. E. 1986. Age at first maturity in Atlantic salmon, Salmo salar: freshwater period influences and conflicts with smolting. In: Meerburg, D. J. (ed.) Salmonid Age at Maturity, vol. 89, pp. 7-14. Can. Spec. Publ. Fish. Aquat. Sci., Ottawa.

THORPE, J. E. 1991. Acceleration and deceleration effects of hatchery rearing on salmonid development and their consequences for wild stocks. Aquaculture, 98, 111-118.

THORPE, J. E., MORGAN, R. I. G., TALBOT, C. AND MILES, M. S. 1983. Inheritance of developmental rates in Atlantic salmon, Salmo salar L. Aquaculture, 33, 119-128.

VAN VLECK, L. D. 1972. Estimation of heritability of threshold characters. J. Dairy Sci., 55, 218-225.

WITHLER, R. E., CLARKE, W. C., RIDDELL, B. E. AND KREIBERG, H. 1987. Genetic variation in freshwater survival and growth of chinook salmon (Oncorhynchus tshawytscha). Aquaculture, 64, 85-96.

ZIMMERER, E. J. AND KALLMAN, K. D. 1989. Genetic basis for alternative reproductive tactics in the pygmy swordtail, Xiphophorus nigrensis. Evolution, 43, 1298-1307. 